\title{
Differential expression of extracellular matrix components in the bovine oviduct during the oestrous cycle
}

\author{
C. Gabler ${ }^{1,2}$, G. J. Killian² and R. Einspanier ${ }^{1 *}$ \\ ${ }^{1}$ Institute of Physiology, Technical University München-Weihenstephan, 85350 Freising, \\ Germany; and ${ }^{2}$ The John O. Almquist Research Center, Department of Dairy and Animal \\ Science, The Pennsylvania State University, University Park, PA 16802, USA
}

Components of the extracellular matrix take part in tissue rebuilding as well as activating surface-bound growth factors. In the present study, expression and selected activities of urokinase-type plasminogen activator (uPA), matrix metalloproteinases (MMPs), their inhibitors (plasminogen activator inhibitor 1 (PAI-1) and tissue inhibitors of metalloproteinases (TIMPs)) were examined in bovine oviducts by RT-PCR, ribonuclease protection assay and activity assays. A high content of mRNA encoding for UPA was detected before ovulation with a three-fold decrease after ovulation. In contrast, PAI-1 expression appeared to be stable during the oestrous cycle. Oviductal flushings produced caseinolytic zones in zymograms containing plasminogen at approximately $50 \mathrm{kDa}$ and $28 \mathrm{kDa}$. An activity assay for uPA showed highest net activity during the early to mid-luteal phase.
Increased TIMP-1 and MMP-2 mRNA concentrations were found around the time of ovulation compared with the luteal phase. In contrast, MMP-1 mRNA transcripts were enriched during the early to mid-luteal phase. Gelatin zymograms detected a 70-72 $\mathrm{kDa}$ protease activity showing an oestrous cycle-dependent activity with highest activity before ovulation. Reverse zymography detecting TIMPs revealed proteins between $21 \mathrm{kDa}$ and $24 \mathrm{kDa}$. Only for the smallest $(21 \mathrm{kDa})$ protein were amounts increased around the time of ovulation compared with the luteal phase. The observation that several extracellular matrix components were regulated distinctly in bovine oviducts indicates that local interactions between these components, growth factors, gametes and the embryo are possible and may influence fertilization and early embryonic development.

\section{Introduction}

Mammalian fertilization occurs in the oviduct of the female genital tract. The oviduct and the fluid contained within the oviduct provide a distinct microenvironment that influences sperm capacitation, final oocyte maturation, fertilization and early embryo development.

Chemical analyses have indicated that oviductal fluid is a complex mixture of constituents derived from the plasma plus some specific proteins formed by the oviductal epithelium (Leese, 1988). Recently, fibroblast growth factor 1 and 2 (FGF-1 and -2) (Viuff et al., 1995; Gabler et al., 1997), insulin-like growth factor I (IGF-I) (Schmidt et al., 1994) and vascular endothelial growth factor (VEGF) (Gabler et al., 1999) have been detected in bovine oviductal epithelial cells and in oviductal flushings during the oestrous cycle.

Growth factors are important for the survival of very early embryos. FGF-2 promotes development of bovine embryos beyond the 'eight-cell block' observed in vitro (Larson et al., 1992). VEGF enhances in vitro maturation of oocytes and

*Correspondence

Email: einspani@weihenstephan.de accelerates the development of early embryos (Einspanier et al., 1999). The IGF family, including the ligands IGF-I and II, the receptor type I and binding proteins, is expressed in bovine embryos and in oviductal epithelium (Watson et al., 1992; Winger et al., 1997), and bovine oviductal cell cultures release IGF-I and -II.

These results indicate that there are likely to be autocrine and paracrine oviductal and embryonic growth factor interactions supporting early embryo development in the oviducts.

In bovine oviductal flushings, different concentrations of these growth factors were observed during the oestrous cycle, with highest concentrations before (FGF-2 and VEGF) or after (FGF-1) ovulation (Gabler et al., 1997, 1999). In contrast, mRNA expression of FGF-2 and VEGF showed no variation with stage of oestrous cycle, although an increase in FGF-1 mRNA content was observed in the late luteal phase. In addition, these growth factors are heparin-binding growth factors (Gospodarowicz et al., 1987; Ferrara and Davis-Smyth, 1997) and are localized on the epithelial surface lining the oviductal lumen, which also stains positive for heparan sulphate (Einspanier et al., 1996).

The protease plasmin causes the release of FGF-2 from the extracellular matrix as an active FGF-2-heparan sulphate proteoglycan complex (Saksela and Rifkin, 1990) 
and also cleaves VEGF from heparan sulphate proteoglycans (Houck et al., 1992). The proteolytic cascade of plasmin is initiated by plasminogen activators (PAs), which are serine proteases (for reviews see Danø et al., 1985; Blasi et al., 1987). The PAs convert plasminogen into the active form, plasmin. Two types of PA have been described: the urokinase-type PA (UPA) which is secreted as a single chain molecule of about $50 \mathrm{kDa}$ (pro-uPA) and tissue-type PA (tPA) which exists in one-polypeptide and two-polypeptide chain forms of $70 \mathrm{kDa}$. Pro-uPA is converted by limited proteolysis (for example plasmin) into the active enzyme consisting of two polypeptide chains held together by one disulphide bond. Several distinct protease inhibitors specific for PAs have been described as potent time- and site-specific instruments for the regulation of PA activity. PA inhibitor-1 (PAI-1) is released from different cell types as a protein of about $50 \mathrm{kDa}$. PAI-1 can only inhibit the active two-chain uPA. The localization of UPA appears to be controlled through specific cell-surface receptors (Mayer, 1990).

Another important proteolytic system is the matrix metalloproteinase/tissue inhibitor of metalloproteinase (MMP/TIMP) family, which consists of MMPs and their natural inhibitors, TIMPs (for review see Woessner, 1991). Satoh et al. (1994) identified and described TIMP-1 as an embryogenesis-stimulating factor that was synthesized in a bovine oviductal epithelial cell culture system. The family of TIMPs includes TIMP-1 (28.5 kDa), TIMP-2 (22 kDa), TIMP-3 (24 kDa) and TIMP-4 (22 kDa) (Gomez et al., 1997). TIMP-1 and TIMP-2 can inhibit the activities of all known MMPs, but recent research indicates that TIMP-1 and TIMP-2 are multifunctional proteins with diverse actions (Satoh et al., 1994). TIMP-3 is found exclusively in the extracellular matrix. The recently discovered TIMP-4 may function in a tissue-specific fashion in extracellular matrix haemostasis. The MMP family comprises at least seven proteases ranging from $M_{\mathrm{r}} 28000$ to 92000 . The MMPs are classified into collagenases, gelatinases and stromelysins. Together they possess the ability to degrade components of the extracellular matrix through a zinc-catalysed mechanism. All family members are secreted as zymogens that lose peptides of about $10 \mathrm{kDa}$ upon activation through, for example, plasmin or trypsin (Woessner, 1991).

Furthermore, growth factors play a central role in the regulation of degradation and remodelling of the extracellular matrix (Gospodarowicz et al., 1987; Ferrara and Davis-Smyth, 1997). This process requires a balance between numerous proteinases and their inhibitors. Such fine tuned regulation occurs during implantation of the embryo in the endometrium in different species (Salamonsen, 1999). Therefore, this autocrine/paracrine crosstalk between growth factors and extracellular matrix components may create an environment in the oviduct ideal for fertilization and early embryo development.

There are many factors that influence fertilization and early embryonic development in the oviducts,. However, little is known about extracellular matrix components in bovine oviducts during the oestrous cycle. This study focuses on the plasmin-plasminogen system because of its ability to release growth factors from the extracellular matrix, and on the TIMP-1/MMP system, which has embryotrophic activity.

The aims of this study were: (i) to examine oviductal cells as a source for $\mathrm{mRNA}$ expression and protein production of uPA, PAI-1, TIMP-1, MMP-1 and -2; (ii) to evaluate the secretions of the oviduct for the activity of PAs, MMPs and TIMPs using zymographic approaches; and (iii) to perform mRNA and enzymatic assays throughout the oestrous cycle to reveal temporal changes under hormonal influences in bovine oviducts in vivo.

\section{Materials and Methods}

\section{Tissue collection}

Oviducts from adult German Fleckvieh cows (Bos taurus) were collected at a local abattoir within 20 min of death. The stage of the oestrous cycle was defined by careful examination of the ovaries (follicles and corpora lutea) and the uterus (Ireland et al., 1980). These criteria were used to classify the oviducts into four groups: post-ovulatory stage (days 1-5), early to mid-luteal stage (days 6-12), late luteal stage (days 13-18) and the pre-ovulatory stage (days 19-21). For RNA and protein analyses, the oviducts were filled with $1 \mathrm{ml}$ Ringer's solution (Fresenius AG, Bad Homburg) and the oviductal contents were squeezed in a $1.5 \mathrm{ml}$ microfuge tube. The supernatant was used again for the same oviduct and the procedure was repeated. After centrifugation at $570 \mathrm{~g}$ for $3 \mathrm{~min}$ at $4^{\circ} \mathrm{C}$, the supernatants and cell pellets were stored separately at $-80^{\circ} \mathrm{C}$. Preliminary mRNA analyses indicated no oestrous cycle-specific effect on ipsilateral versus contralateral localization within the oviducts. Therefore, oviductal cells and flushings obtained from both oviducts of individual cows were combined for further analyses.

Verification of the cell types and viability of oviductal cells was performed as described by Gabler et al. (1997). In brief, viability of the flushed cells was confirmed by observation of beating cilia under a microscope, as well as by exclusion of Trypan blue. Immunohistochemical analysis of the flushed cells using cytokeratin as an epithelial cell specific marker showed a positive staining of $>60 \%$ of the cells. This finding confirms the results of Tiemann et al. (1996), who found a similar range of $50-60 \%$ epithelial cells in flushed oviductal cells. The remaining cells were characterized as stroma cells. Therefore, the flushed cells in the present study were referred to as oviductal cells.

\section{Isolation of RNA}

Total RNA was extracted from oviductal cells using the method described by Chomczynski and Sacchi (1987) with Trizol reagent (Gibco BRL, Grand Island, NY). The yield of total RNA was determined spectroscopically at $260 \mathrm{~nm}$. The quality and quantity of RNA were verified after 
electrophoresis on a $1 \%(\mathrm{w} / \mathrm{v})$ formaldehyde-containing agarose gel by ethidium bromide staining.

\section{Reverse transcription-polymerase chain reaction (RT-PCR)}

Reverse transcription was performed in a volume of $60 \mu \mathrm{l}$ using $4 \mu \mathrm{g}$ oviductal cell total RNA, $2.5 \mu \mathrm{mol}$ random hexamers ${ }^{-1}$ (Pharmacia, Freiburg) and Superscript II reverse transcriptase (Gibco BRL) as described by Gabler et al. (1998).

The following commercially synthesized primers (Pharmacia) were used to amplify specific bovine transcripts: uPA (Krätzschmar et al., 1993) (460 bp): forward 5' TAACCTACAAGTACTTCTC $3^{\prime}$ and reverse 5' GCAAACCAAGGCTGGTTCTC 3'; PAI-1 (Bieser et al., 1998) (363 bp): forward 5' GCTGGTCCATGGTTTCATGC 3' and reverse 5' TCCAGGATGTCGTAGTAACGGC 3'; TIMP-1 (Bieser et al., 1998) (380 bp): forward 5' GATGTCGTCATCAGGGCC $3^{\prime}$ and reverse 5' TCGCTCTGCAGTTTGCAG 3'; MMP-1 (Bieser et al., 1998) (347 bp): forward 5' GATGATGATGAATGGTGGACC 3' and reverse 5' TCCACTTCTGGGTACAAGGGA 3'; and MMP-2 (corresponding to bases 52-310 of the bovine sequence: EMBL number AF135231) (259 bp): forward 5' CCCAGACAGTGGATGATGC 3' and reverse 5' ACACGGACCACTTGTCCTTC 3'. The predicted size of each RT-PCR product is assigned in parentheses.

$\mathrm{PCR}$ reactions were performed in a thermocycler (Personal Cycler; Biometra, Göttingen). The reaction mixture containing 0.5 U Primezyme (Biometra) (for UPA, TIMP-1 and MMP-2) or $0.5 \cup$ Taq polymerase (Boehringer Mannheim, Mannheim) (for PAI-1 and MMP-1) was as described by Gabler et al. (1997). Each reaction was started with an initial denaturation step for $2 \mathrm{~min}$ at $94^{\circ} \mathrm{C}$ followed by individual amplification programmes: uPA: 30 cycles at $94^{\circ} \mathrm{C}$ and $55^{\circ} \mathrm{C}, 1$ min each; PAl-1: 37 cycles at $94^{\circ} \mathrm{C}$ and $60^{\circ} \mathrm{C}$, 1 min each; MMP-1: 37 cycles at $94^{\circ} \mathrm{C}$ and $57^{\circ} \mathrm{C}$, $1 \mathrm{~min}$ each; MMP-2: 31 cycles at $94^{\circ} \mathrm{C}$ and $60^{\circ} \mathrm{C}, 1 \mathrm{~min}$ each; and TIMP-1: 32 cycles at $94^{\circ} \mathrm{C}$ and $60^{\circ} \mathrm{C}, 1$ min each. As a final step, an elongation phase was performed for $2 \mathrm{~min}$ at $72{ }^{\circ} \mathrm{C}$. An aliquot $(5 \mu \mathrm{l})$ of each reaction was subjected to electrophoresis on a $1.5 \%(\mathrm{w} / \mathrm{v})$ agarose gel containing $1 \mu \mathrm{g}$ ethidium bromide $\mathrm{ml}^{-1}$. After electrophoresis, the gels were scanned by a video documentation system (Pharmacia). As a negative control, diethylpyrocarbonate-treated water was used instead of RNA to exclude any contamination. Conditions for the PCR were optimized for each factor, thus ensuring that the amplification did not reach a plateau, as verified by use of increasing cycle numbers in preliminary experiments.

As described by Gabler et al. (1999), an RT-PCR for the housekeeping gene ubiquitin was performed to control the integrity of the RNA, as well as the efficiency of the reverse transcription for each sample. The expression of two ubiquitin-specific RT-PCR products (189 and 417 bp) was constant during the different phases of the oestrous cycle in
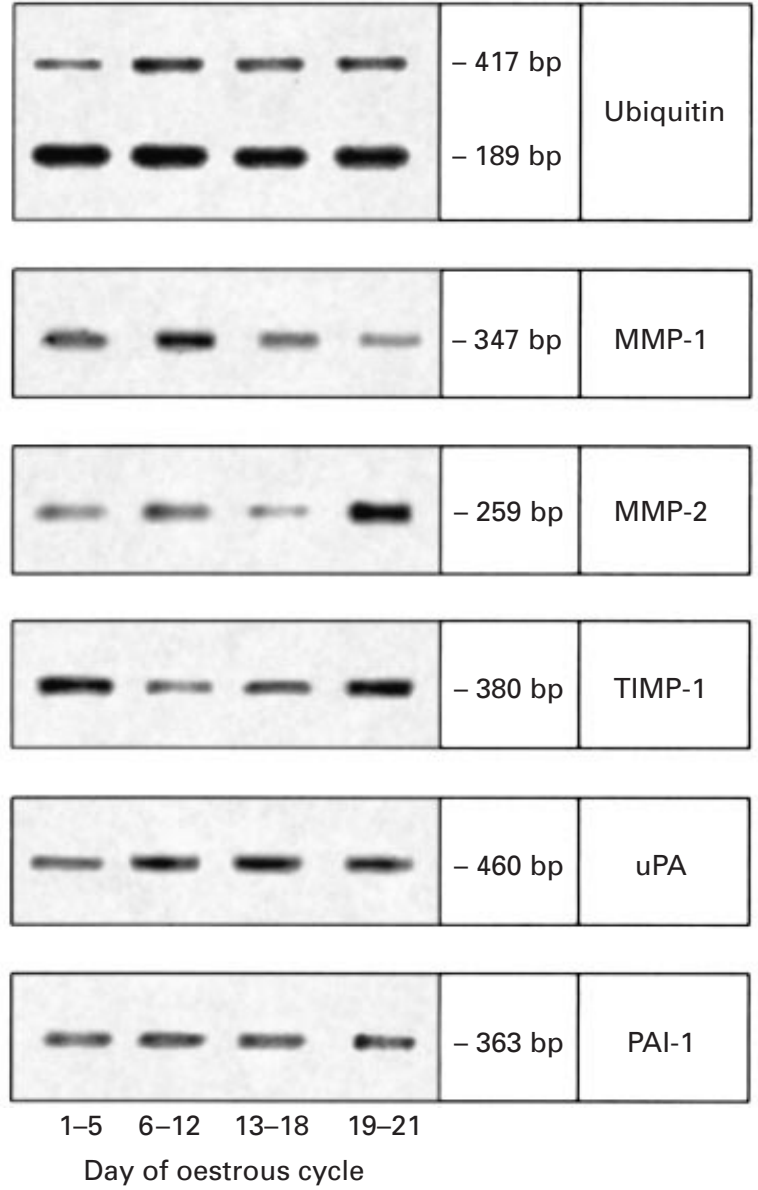

Fig. 1. Specific RT-PCR products for ubiquitin (189 and $417 \mathrm{bp}$ ), matrix metalloproteinase 1 (MMP-1; 347 bp), MMP-2 (259 bp), tissue inhibitor of metalloproteinase 1 (TIMP-1; $380 \mathrm{bp}$ ), urokinase-type plasminogen activator (uPA; $460 \mathrm{bp}$ ) and plasminogen activator inhibitor 1 (PAI-1; $363 \mathrm{bp}$ ) in bovine oviductal cells separated by agarose gel electrophoresis. Days 1-5: post-ovulatory phase; days 6-12: early to mid-luteal phase; days 13-18: late luteal phase; and days 19-21: pre-ovulatory phase ( $n=4$ cows for each phase of the oestrous cycle).

the bovine oviducts, indicating that the same amounts of RNA were used in all samples (Fig. 1). In addition, these ubiquitin expression data showed that the activity for the maintenance and survival of the cell was constant throughout the oestrous cycle.

Specificity of the RT-PCR products was verified after subcloning into the pCR-Script ${ }^{\mathrm{TM}} \mathrm{SK}(+)$ cloning vector (Stratagene, La Jolla, CA) followed by DNA sequencing (TOPLAB, Munich).

\section{Ribonuclease protection assay}

Total oviductal RNA $(30 \mu \mathrm{g})$ was introduced into a ribonuclease protection assay (RPA II kit; Ambion, Austin, TX) and performed as described by Plath et al. (1996). In 
brief, antisense RNA probes were labelled with $\alpha^{32}$ P-CTP (800 Ci mmol-1; Amersham, Little Chalfont). After $20 \mathrm{~h}$ hybridization, RNase digestion buffer (2.5 U RNase A ml-1 and $100 \mathrm{U}$ RNase $\mathrm{T} 1 \mathrm{ml}^{-1}$ ) was added to each sample. Protected mRNA fragments were detected by horizontal gel electrophoresis and autoradiography for 3 days, 14 days or 1 month. Distinct concentrations of sense RNAs synthesized in vitro were introduced in each ribonuclease protection assay to quantify these mRNA transcripts. The signal intensities obtained for these standardized sense RNAs were compared with those of the total oviductal RNA samples. As a negative control, $30 \mu \mathrm{g}$ yeast RNA was used for the ribonuclease protection assay.

\section{Zymography}

Zymographic detection on substrate gels was used to characterize distinct proteinase activity. Gels were prepared as described by Herron et al. (1986; for MMP detection) or Heussen and Dowdle (1980; for PA detection). In brief, SDS polyacrylamide $(10 \% \mathrm{w} / \mathrm{v})$ gels were polymerized with $1 \mathrm{mg}$ gelatin type $\mathrm{A} \mathrm{ml}^{-1}$ (Fisher Scientific, Pittsburgh, PA) or $1 \mathrm{mg}$ casein $\mathrm{ml}^{-1}$ (Merck, Darmstadt) and $40 \mu \mathrm{g}$ plasminogen $\mathrm{ml}^{-1}$ (Boehringer Mannheim). Only casein was added as a substrate to the SDS polyacrylamide gels as a negative control for the detection of plasminogen activators to exclude any other protease activity. Oviductal flushings $(9 \mu \mathrm{l})$ were loaded in non-reducing loading buffer onto the gels. After electrophoresis, gels were washed $($ two $\times 30 \mathrm{~min}$ ) with $2.5 \%(\mathrm{v} / \mathrm{v})$ Triton $\mathrm{X}-100$ (Sigma, Deisenhofen) in $50 \mathrm{mmol}^{\text {Tris }} \mathrm{I}^{-1}$ (pH 7.6), rinsed three times with incubation buffer (50 mmol Tris $\mathrm{I}^{-1}(\mathrm{pH} 7.8)$, $150 \mathrm{mmol} \mathrm{NaCl} \mathrm{I}{ }^{-1}$ and $\left.5 \mathrm{mmol} \mathrm{CaCl}_{2}\right|^{-1}$ ), followed by an incubation for $14-16 \mathrm{~h}$ at $37^{\circ} \mathrm{C}$. After staining in Coomassie brilliant blue R 250 (Merck; 0.25\% (w/v) in 45\% (v/v) methanol and $10 \%(\mathrm{v} / \mathrm{v})$ glacial acetic acid) for $1 \mathrm{~h}$, the gels were destained in $45 \%(\mathrm{v} / \mathrm{v})$ methanol and $10 \%(\mathrm{v} / \mathrm{v})$ glacial acetic acid.

TIMPs were analysed with reverse gelatin zymography as described by Oliver et al. (1997) with slight modifications. In brief, $12 \%(\mathrm{w} / \mathrm{v})$ SDS polyacrylamide gels were made

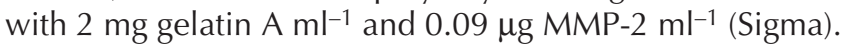
Oviductal flushings $(9 \mu \mathrm{l})$ were loaded in non-reducing loading buffer onto the gels. The gels were run and treated under the same conditions described above. The activity of TIMPs resulted in the presence of dark blue bands on a clear background. SDS polyacrylamide gels without substrates were used as controls.

Each polyacrylamide gel included one lane containing $8 \mu \mathrm{l}$ of a high or low molecular mass marker (Sigma). The molecular masses of the proteolytic or blue zones were calculated using Gel-Pro Analyzer software (Media Cybernetics, Silver Spring, MD).

\section{Urokinase-type plasminogen activator activity assay}

uPA activity in oviductal flushings was measured using a modified chromogenic assay described by Karlan et al.
(1987). The assays were carried out in $100 \mu \mathrm{l}$ volumes in 96-well flat-bottomed microtitre plates. Incubation volumes consisted of $25 \mu \mathrm{l}$ oviductal flushing, $30 \mu \mathrm{l}$ incubation buffer (50 mmol Tris $\mathrm{I}^{-1}(\mathrm{pH} 8.2)$ and $\left.100 \mathrm{mmol} \mathrm{NaCl} \mathrm{I}^{-1}\right)$, $25 \mu$ l Chromozym ${ }^{\circledR}$ PL (Boehringer Mannheim) solution as described by the supplier, $20 \mu \mathrm{l} 1 \mathrm{mg}$ plasminogen $\mathrm{ml}^{-1}$ in $50 \mathrm{mmol}$ Tris l-1 (pH 7.5), $100 \mathrm{mmol} \mathrm{NaCl} \mathrm{I}^{-1}, 1 \mathrm{mmol}$ EDTA $^{-1}$ and $0.01 \%(\mathrm{v} / \mathrm{v})$ Tween 80 . Time zero represented the time of addition of plasminogen. The PA activity results in generating plasmin, cleaving the colourless Chromozym ${ }^{\circledR}$ PL to yield the yellow 4-nitroaniline. Production of 4nitroaniline was quantified at $405 \mathrm{~nm}$ on an automated microtitre plate reader every $10 \mathrm{~min}$ until it reached a plateau. PA activity in all samples was referenced to human urokinase (Calbiochem, San Diego, CA) standard curves (0.005-1.000 $\mathrm{U} \mathrm{ml}^{-1}$ ) run in each experiment.

Each sample was performed in this assay as a duplicate. For controls, Chromozym ${ }^{\circledR} \mathrm{PL}$ or plasminogen was replaced with incubation buffer to exclude the possibility of any contamination.

\section{Densitometric and statistical analysis}

Gels of mRNA and protein analyses were digitized by a video documentation system (Pharmacia) three times with different settings. Scanned band intensities of the obtained RT-PCR products, protected mRNA fragments in the ribonuclease protection assay, clear or blue zones in the zymographs were estimated using the Gel-Pro Analyzer software after subtraction of background. The background subtraction was checked manually for each lane. No obvious variations were found among the three different documentation settings. Furthermore, all data were compared with the visual impression of the band intensities.

All data from zymographs, uPA activity assay, RT-PCR and RPA were analysed by ANOVA. When ANOVA showed significant differences, the Bonferroni test was used to test significance. These calculations were performed with InStat (Version 3.0; GraphPad Software, San Diego, CA).

\section{Results}

\section{Plasminogen system}

UPA and PAI-1 mRNA transcripts were detected in bovine oviductal cells by RT-PCR (Fig. 1). Both components of the plasminogen system, found for the first time in bovine oviducts, showed a remarkable pattern of expression during the oestrous cycle: the concentrations of uPA mRNA were lowest after ovulation (days 1-5) but increased two- to three-fold during the early to mid-luteal phase (days 6-12) and remained at this level until ovulation. This expression pattern was confirmed by the quantitative ribonuclease protection assay (Fig. 2), indicating a significant decrease from higher uPA mRNA concentrations during the preovulatory phase (days 19-21) compared with after ovulation (days 1-5).

After the introduction of standardized UPA sense RNA 
(a)

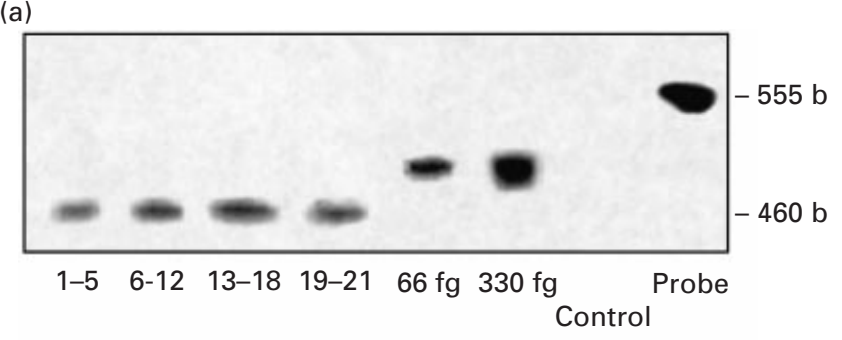

(b)

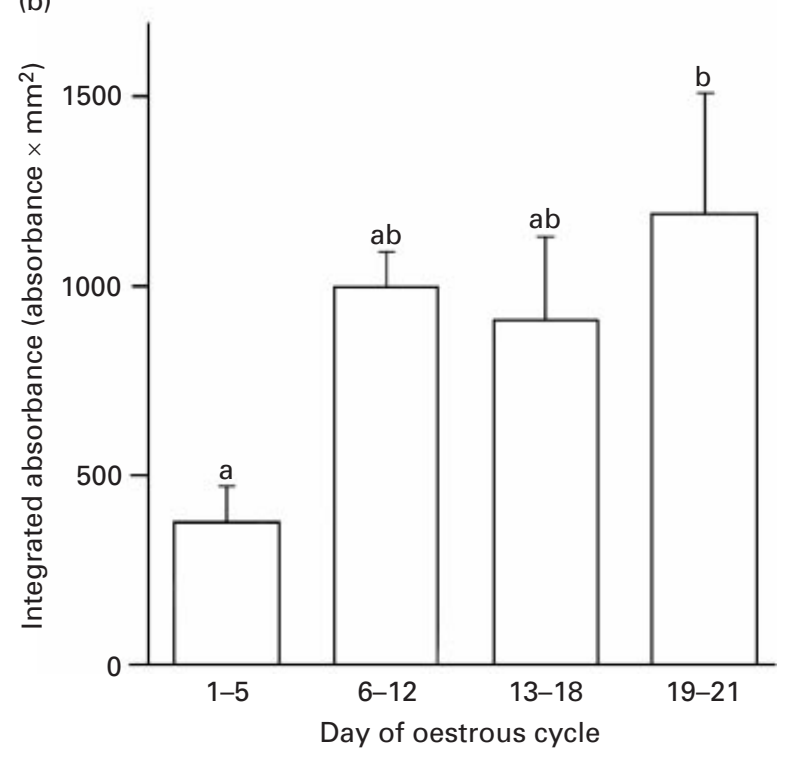

Fig. 2. Ribonuclease protection assay using ${ }^{32} \mathrm{P}$-labelled antisense RNA probes showing the mRNA specific for urokinase-type plasminogen activator (UPA) in bovine oviductal cells (days 1-5: post-ovulatory phase; days 6-12: early to mid-luteal phase; days 13-18: late luteal phase; and days 19-21: pre-ovulatory phase). (a) One representative result out of four for each phase of the oestrous cycle is shown (control: control with yeast RNA; $66 \mathrm{fg}$ and $330 \mathrm{fg}$ are sense UPA RNA standard concentrations). (b) The corresponding integrated absorbance (mean \pm SEM; $n=4$ cows for each phase of the oestrous cycle) is depicted. ${ }^{a b}$ Different letters indicate significant differences between columns $(P<0.05)$.

into the ribonuclease protection assay, the following mean concentrations were found (per $1 \mu \mathrm{g}$ total RNA): $25 \mathrm{fg}$ during the post-ovulatory phase (days 1-5) and about $60 \mathrm{fg}$ during the other phases (days 6-12, 13-18 and 19-21).

In contrast to uPA, PAI-1 expression showed no significant variation during the oestrous cycle in oviductal cells using the very sensitive RT-PCR technique (Fig. 1). Owing to the low transcription of PAI-1, the ribonuclease protection assay did not give detectable results.

When plasminogen-activating zymograms were performed using bovine oviductal flushings, two areas indicating plasmin-generating activity were detected. A predominant double band at approximately 50-52 kDa was observed at all phases of the oestrous cycle and a weaker double

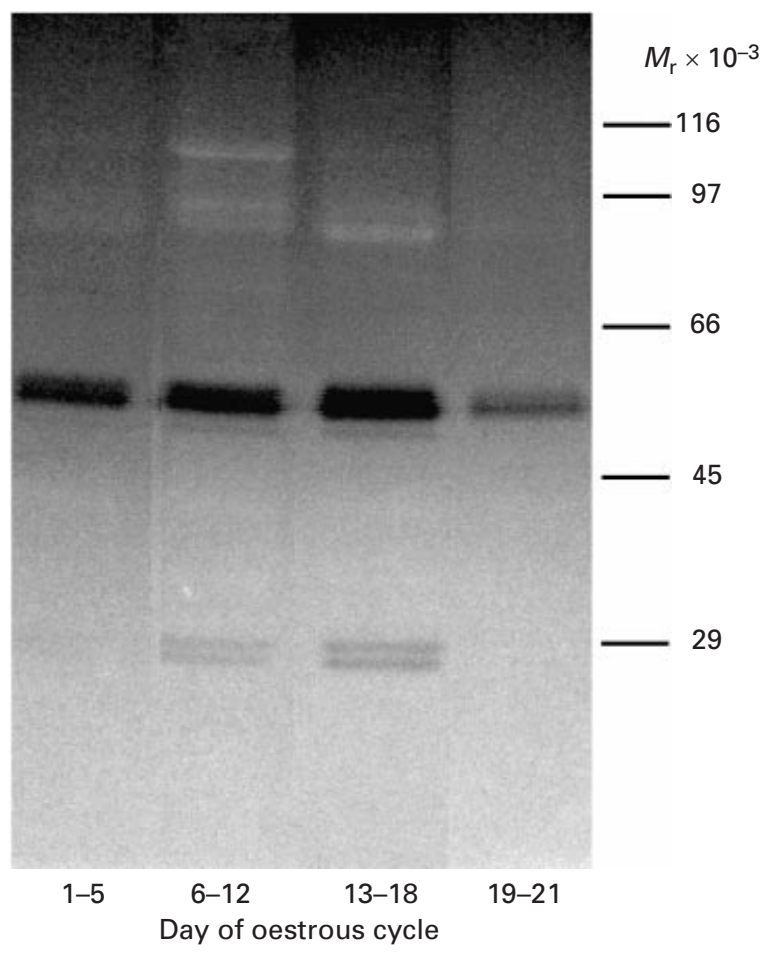

Fig. 3. Stained zymogram (inversed picture) containing casein and plasminogen for detection of plasminogen activator of bovine oviductal flushings. Days 1-5: post-ovulatory phase; days 6-12: early to mid-luteal phase; days 13-18: late luteal phase; and days 19-21: pre-ovulatory phase. One representative result out of four is shown for each phase of the oestrous cycle. Plasminogen activator activity is higher during the luteal phase compared with around the time of ovulation.

band at approximately 27-28 kDa was present during the luteal phase only (Fig. 3). Zymography revealed a higher PA activity during the luteal phase compared with the time around ovulation. The negative control in which plasminogen was omitted from the polyacrylamide gel showed no protease activity (data not shown). A highly sensitive chromogenic microtitre plate assay was used and a significant increase in net uPA activity was observed from the post-ovulatory phase to the highest activity during the early to mid-luteal phase, and a significant decrease was observed during the late luteal phase (Fig. 4).

\section{Matrix metalloproteinase system}

In addition to the plasminogen system, selected components of the matrix metalloproteinase system were detected in the bovine oviduct by RT-PCR and zymography. RT-PCR analysis showed that MMP-1 and MMP-2 were expressed in the bovine oviducts during all stages of the oestrous cycle (Fig. 1). Significantly higher MMP-1 mRNA content was found during the early to mid-luteal phase compared with the other stages of the oestrous cycle $(P<0.01)$ (Fig. 5a). The MMP-1 mRNA concentrations 


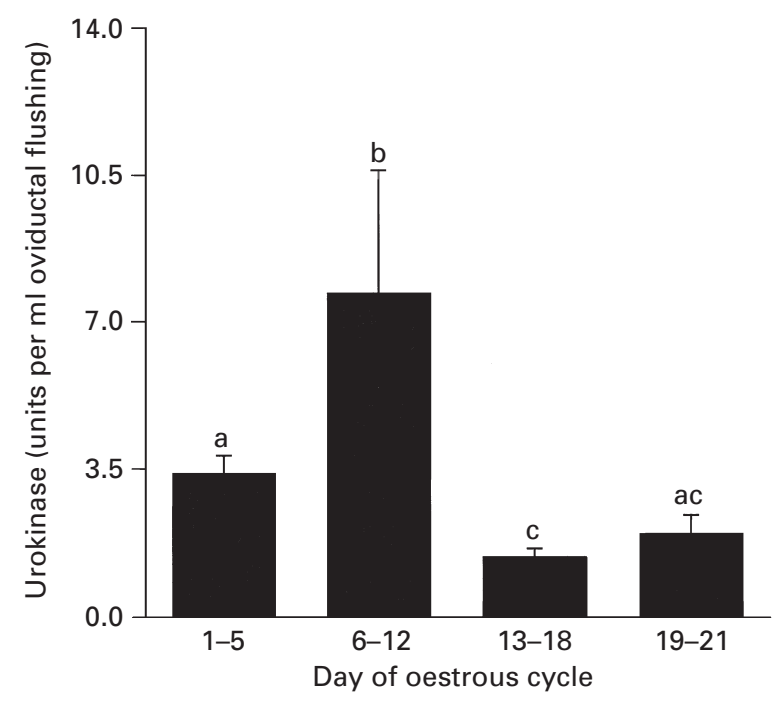

Fig. 4. Net urokinase-type plaminogen activator (uPA) activities in bovine oviductal flushings. Days 1-5: post-ovulatory phase; days 6-12: early to mid-luteal phase; days 13-18: late luteal phase; and days 19-21: pre-ovulatory phase. Values are mean \pm SEM $(n=6$ cows for each phase of the oestrous cycle). ${ }^{a b c}$ ifferent letters indicate significant differences between columns $(P<0.05)$.

decreased to one quarter during the late luteal phase and a slight increase was observed during the post-ovulatory phase. In contrast, significantly higher MMP-2 mRNA concentrations were found in the pre-ovulatory phase but decreased thereafter to lowest concentrations in the late luteal phase (Fig. 5b).

In gelatin zymograms, a 70-72 kDa protease activity was detected in oviductal flushings (Fig. 6a). The densitometric analysis of these zymographs showed that gelatinase activities were significantly higher during the pre-ovulatory phase (days 19-21) and decreased after ovulation to the lowest activities during the luteal phase (Fig. 6b). No detectable caseinolytic activity was observed in casein zymograms (data not shown).

The expression pattern of the inhibitor TIMP-1 was similar to MMP-2, showing increased mRNA contents before ovulation. TIMP-1 RT-PCR results were confirmed by ribonuclease protection assay (Fig. 7): highest expression was found after ovulation (days 1-5) and a significant threefold decrease was observed during the early to mid-luteal phase. A significant two-fold increase was then observed during the pre-ovulatory phase (days 19-21). On the basis of the sense TIMP-1 RNA standards, the following mean mRNA concentrations were measured: about 70 fg specific TIMP-1 transcript $\mu \mathrm{g}^{-1}$ total RNA was present around ovulation and about $30 \mathrm{fg}$ specific TIMP-1 transcript $\mu \mathrm{g}^{-1}$ total RNA during the luteal phase (Fig. 7).

Furthermore, during this period of highest TIMP-1 expression (pre- and post-ovulatory phases) a higher TIMP-1 mRNA content was found by ribonuclease protection assay and RT-PCR in the oviduct ipsilateral to the site of ovulation
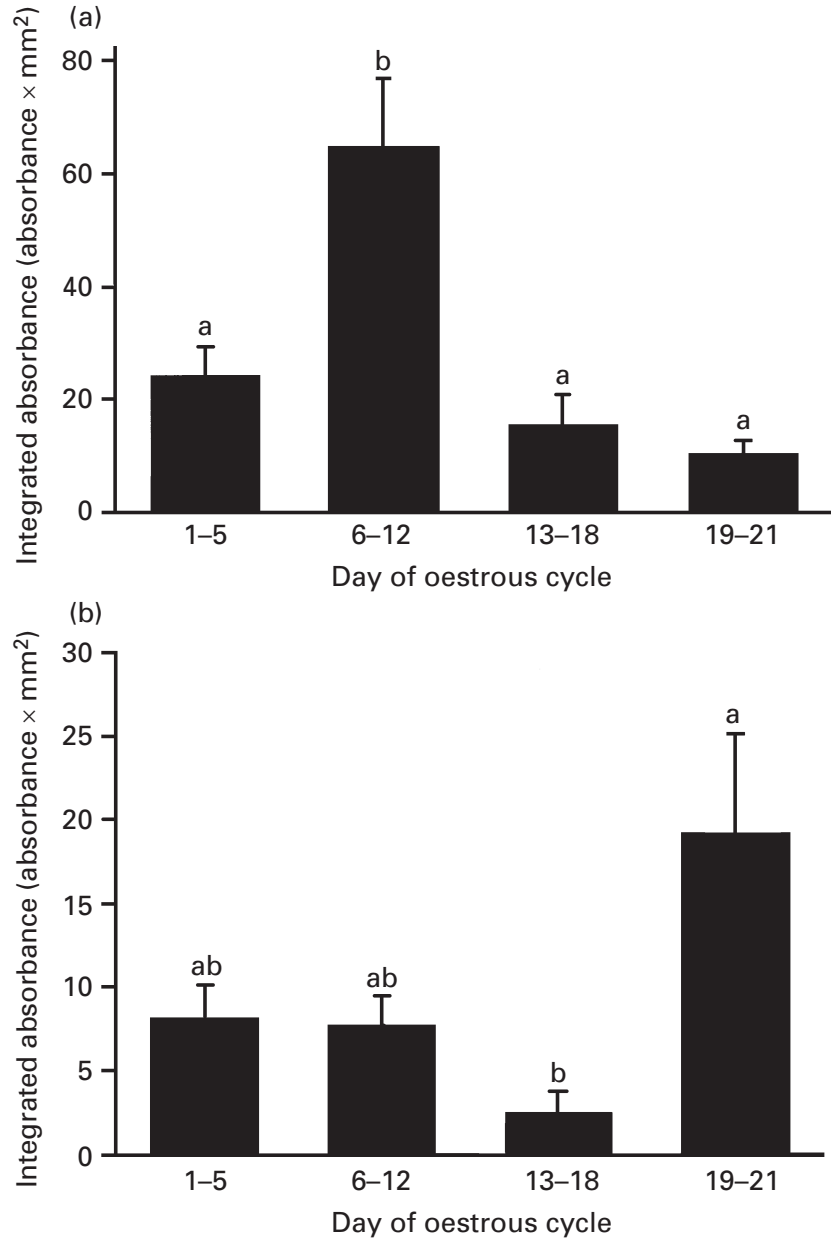

Fig. 5. Densitometric analysis of specific RT-PCR for (a) matrix metalloproteinase 1 (MMP-1) and (b) matrix metalloproteinase 2 (MMP-2) in bovine oviductal cells. Days 1-5: post-ovulatory phase; days 6-12: early to mid-luteal phase; days 13-18: late luteal phase; and days 19-21: pre-ovulatory phase. The integrated absorbance (mean $\pm \mathrm{SEM} ; n=4$ cows for each phase of the oestrous cycle) is shown. Different letters indicate significant differences between columns: for MMP-1: a versus b: $P<0.01$; and for MMP-2: a versus b: $P<0.05$.

compared with the contralateral oviduct (data not shown). For the other components (UPA, PAI-1, MMP-1 and -2) no obvious differences were observed in the expression for the two sides of the oviduct.

Reverse zymography revealed that oviductal flushings contained three factors that inhibited gelatinase activity (Fig. 8a). Two main inhibitors of approximately 21 and 22 kDa showed high TIMP-like inhibitory effects, whereas only a very weak inhibition was observed for the third factor (24 kDa). In SDS polyacrylamide gels without gelatin and MMP-2 (gelatinase A), oviductal flushings did not contain visible proteins in the range 20-30 kDa with Coomassie blue staining (Fig. 8a, lane 5). Therefore, the three bands visible in Fig. 8 (lanes $1-4$ ) represent undegraded gelatin, 
(a)

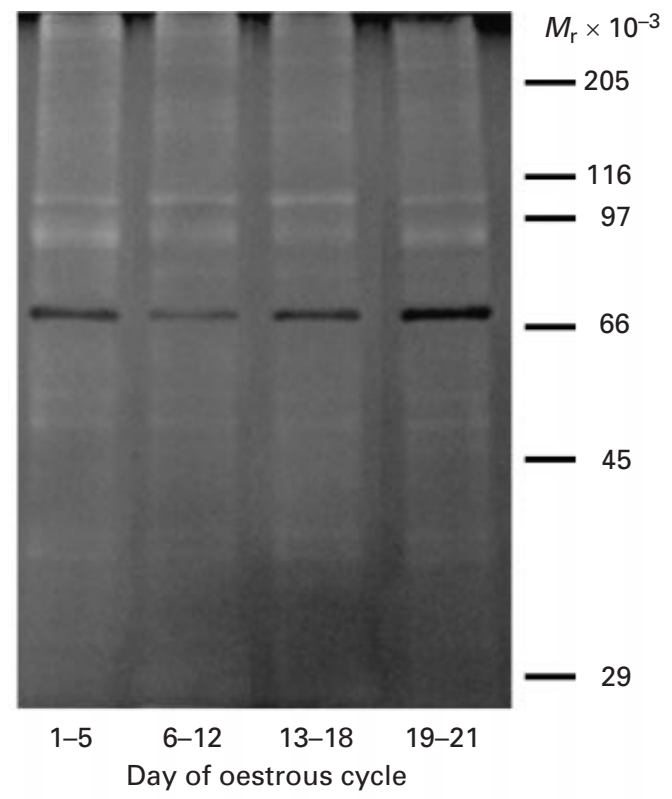

(b)

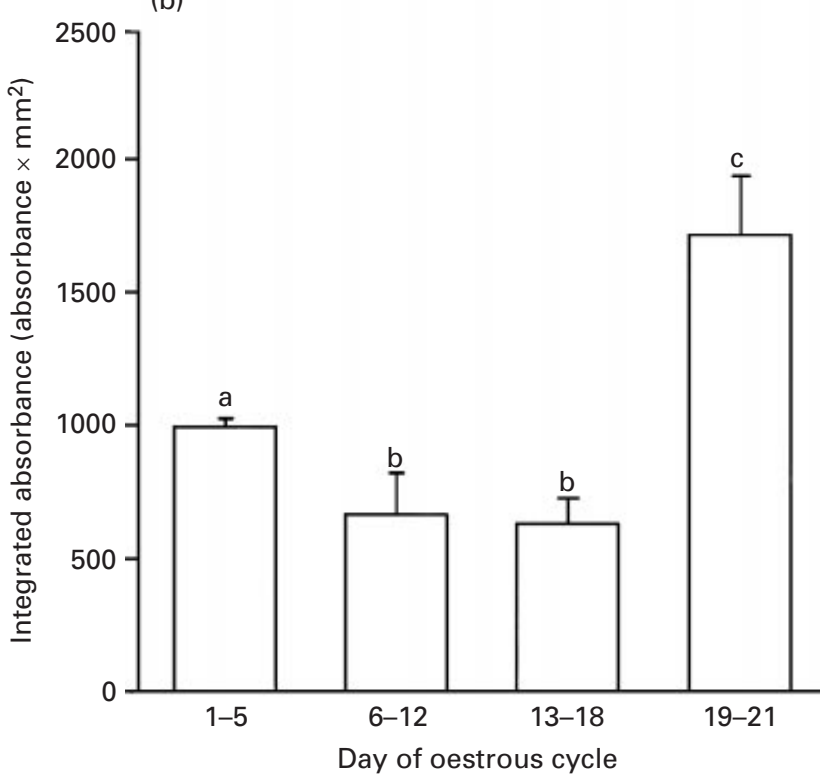

Fig. 6. (a) Stained zymogram (inversed picture) detecting matrix metalloproteinases containing gelatin of bovine oviductal flushings. Days 1-5: post-ovulatory phase; days 6-12: early to midluteal phase; days 13-18: late luteal phase; and days 19-21: preovulatory phase. One representative result out of four is shown for each phase of the oestrous cycle. (b) Corresponding integrated absorbance (mean $\pm \mathrm{SEM} ; n=4$ cows for each phase of the oestrous cycle) of the clear zones is shown. abcDifferent letters indicate significant differences between columns $(P<0.01)$.

which was the result of inhibition of MMP-2 by these three bands. Stained bands at $36 \mathrm{kDa}$ and higher molecular masses were also present in the control lane. Both inhibitors at $22 \mathrm{kDa}$ and $24 \mathrm{kDa}$ showed no significant oestrous cycle-
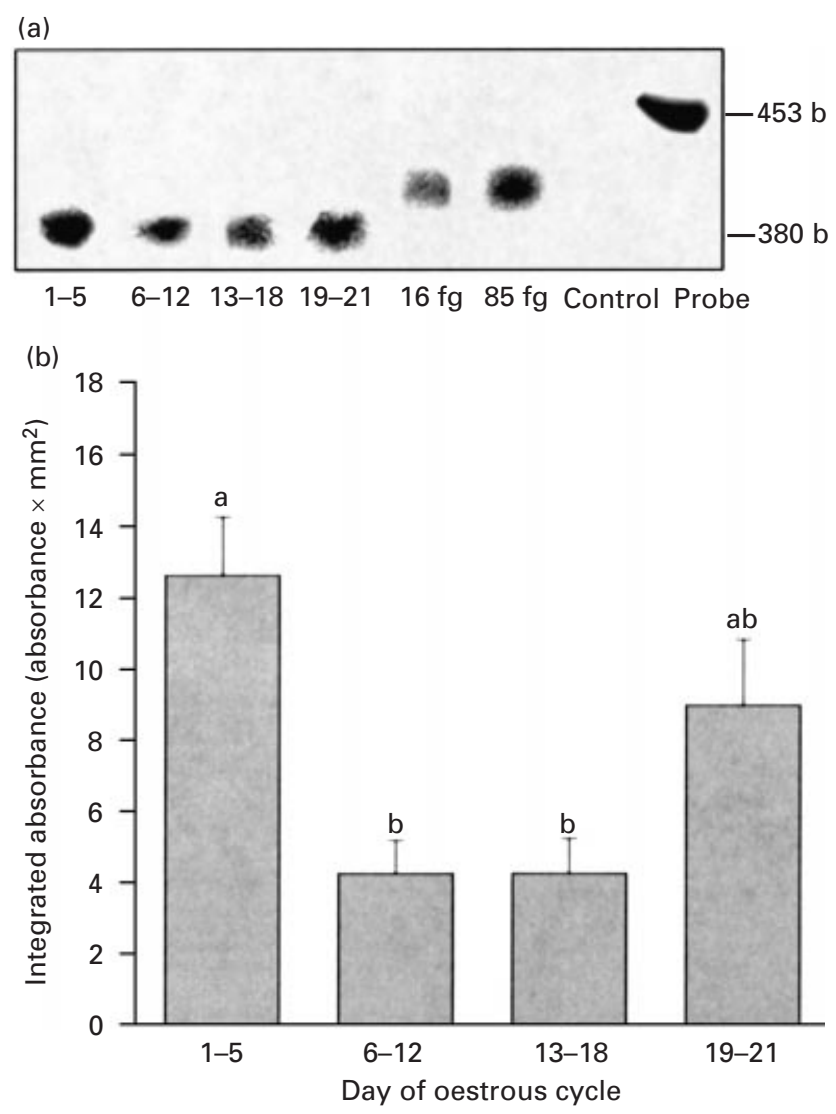

Fig. 7. Ribonuclease protection assay using ${ }^{32}$ P-labelled antisense RNA probes showing the mRNA specific for tissue inhibitor of metalloproteinase 1 (TIMP-1) in bovine oviductal cells. Days 1-5: post-ovulatory phase; days 6-12: early to mid-luteal phase; days 13-18: late luteal phase; and days 19-21: pre-ovulatory phase. (a) One representative result out of four for each phase of the oestrous cycle is shown. Control: control with yeast RNA; $16 \mathrm{fg}$ and 85 fg are sense TIMP-1 RNA standard concentrations. (b) Corresponding integrated absorbance (mean \pm SEM; $n=4$ cows for each phase of the oestrous cycle) is shown. ${ }^{a b}$ Different letters indicate significant differences between columns $(P<0.05)$.

specific variation. However, the inhibitory activity of the $22 \mathrm{kDa}$ protein revealed great sample-to-sample variation among single oviduct flushings and resulted in a high standard deviation for each phase of the oestrous cycle (data not shown).

Significant oestrous cycle-dependent regulation was observed for the $21 \mathrm{kDa}$ gelatinase inhibitor only. The greatest inhibition was detected after ovulation (days $1-5$ ), but the inhibitory effect decreased during the luteal phase and increased during the pre-ovulatory phase (Fig. 8b).

\section{Discussion}

The results of the present study show that the oviduct is a source of both proteases and their specific inhibitors. Transcripts for uPA were detected using RT-PCR and a 


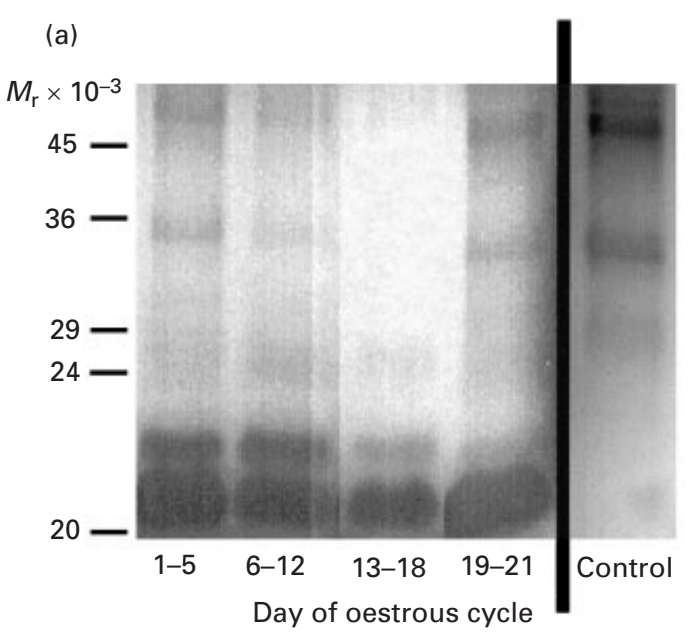

(b)

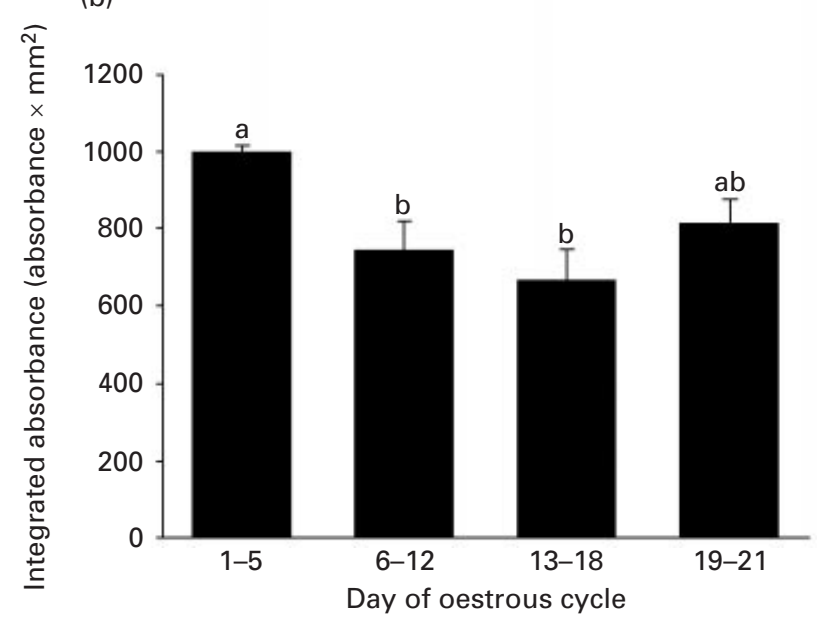

Fig. 8. (a) Stained reverse zymogram detecting tissue inhibitors of metalloproteinases (TIMPs) containing gelatin and matrix metalloproteinase 2 (MMP-2) of bovine oviductal flushings. Days 1-5: post-ovulatory phase; days 6-12: early to mid-luteal phase; days 13-18: late luteal phase; and days 19-21: pre-ovulatory phase. Control: control without MMP-2 and casein. One representative result out of four is shown for each phase of the oestrous cycle. (b) Corresponding integrated absorbance (mean \pm SEM $; n=4$ cows for each phase of the oestrous cycle) of the blue zones of the $21 \mathrm{kDa}$ TIMP are depicted. ${ }^{\mathrm{ab}}$ Different letters indicate significant differences between columns $(P<0.01)$.

ribonuclease protection assay. Furthermore, zymography revealed that the PA activity was of approximately 50-52 kDa, which corresponded to the known molecular mass of uPA, but not with tPA possessing a molecular mass of about $70 \mathrm{kDa}$ (Danø et al., 1985). In addition, a second double band was found in some samples at about 27-28 kDa. The same activity region of $28 \mathrm{kDa}$ and $48 \mathrm{kDa}$ was reported for uPA in bovine capillary endothelial cells (Moscatelli, 1986). This 27-28 kDa double band may represent the bovine equivalent of the human $33 \mathrm{kDa}$ form of UPA, which is a degradation product of the higher molecular mass form reported by Blasi et al. (1987). This form lacks an amino terminal fragment, but still maintains its catalytic activity. These results indicate that oviductal cells synthesize and secrete uPA pro-enzyme, which possesses little or no activity (Blasi et al., 1987). Traces of plasmin could activate uPA into the highly active two-chain form. An increase in uPA mRNA concentration and net activity of UPA in the oviduct was found during the early to mid-luteal phase. Surprisingly, the mRNA expression remained high until ovulation, but the enzyme activity decreased during the late luteal phase. However, high uPA protein contents were observed during the early to mid- and late luteal phases by zymography. The reason for the different regulation of $\mathrm{UPA}$ mRNA expression, protein content and activity may be due to the existence of PA inhibitors. A low, but steady, expression of PAI-1, a specific inhibitor of uPA, was observed. In pig oviducts, PAI-1 was detected in the oviductal fluid as well as in the apical region of the epithelial cells by immunohistochemistry (Kouba et al., 2000a). In addition, a greater amount of PAI-1 mRNA was found in the isthmus compared with other segments of pig oviducts (Kouba et al., 2000b), in contrast to the lack of regional difference found in bovine oviducts. Two other PA inhibitors, PAI-2 and nexin (Blasi et al., 1987), may also be present in the oviduct to inhibit uPA. These results indicate that there is a well-balanced protease and inhibitor system within the bovine oviduct, especially around the time of ovulation, that protects the gametes and the developing embryo from proteolytic degradation in the oviductal lumen.

The plasminogen-plasmin system works predominantly at cell-cell or cell-substrate contact areas (Saksela and Rifkin, 1988), suggesting that the release of heparin-binding growth factors (FGFs and VEGF) from the oviductal surface lining into the bovine oviductal lumen occurs by a PAregulated mechanism. However, the highest VEGF and FGF-2 concentrations were detected before ovulation in oviductal flushings (Gabler et al., 1997, 1999) when the UPA activity was at a minimum. It is possible that oviductal epithelial cells may contain the UPA receptor to bind UPA for cell surface location and that the UPA release from the surface into the oviductal lumen occurs in an oestrous cycle-dependent manner. VEGF, FGF-2 and FGF-2heparan sulphate proteoglycan complexes can stimulate uPA expression and activity (Moscatelli, 1986; Montesano et al., 1986; Saksela and Rifkin, 1990; Pepper et al., 1991).

Matrix metalloproteinases and their inhibitors appear to play an important role in the oviduct and in fertilization. Gelatinase activity was detected in oviductal flushings at approximately $72 \mathrm{kDa}$. This molecular mass agrees with the reported molecular mass of latent MMP-2 (Woessner, 1991). No other proteolytic activity was detected in zymograms containing casein or gelatin. Identification with zymograms is not definitive, as other latent and active MMPs have comparable molecular masses. However, by use of RT-PCR, MMP-2 mRNA transcripts were also 
detected in bovine oviductal cells. The expression pattern of MMP-2 showed the same oestrous cycle-dependent regulation as did the $72 \mathrm{kDa}$ gelatinase activity. This finding supports the contention that MMP-2 is produced by oviductal cells and secreted into the oviductal lumen. The quantity of mRNA and protein of MMP-2 increased significantly in the pre-ovulatory phase, indicating that this enzyme may be involved in events associated with fertilization. Bieser et al. (1998) reported a marked increase in MMP-2 activity in cumulus-oocyte complexes matured in vitro. These results and the data obtained in the present study indicate that MMP-2 may be involved in ovum cumulus expansion and sperm-egg interactions as part of a successful fertilization. MMP-2 appears to be secreted in the latent $72 \mathrm{kDa}$ form, but no MMP-2 of the active $66 \mathrm{kDa}$ form was detected. Various proteases, such as plasmin, can activate such latent secreted MMP-2 (Mazzieri et al., 1997). This finding indicates that the plasmin-generating system in the oviduct may also be involved in the activation of latent MMPs. In addition, MMP-1 specific mRNA was detected in bovine oviductal cells, but no corresponding area was observed in the zymographs. These data indicate that the localization of MMP-1 and MMP-2 may be different as, in contrast to MMP-1, MMP-2 activity was found in oviductal flushings. Furthermore, the regulation of MMP-1 during the oestrous cycle is completely different from that of MMP-2, with the highest expression in the early to mid-luteal phase. These results indicate that MMP-1 may have a different function from MMP-2 and may be involved in matrix turnover.

In addition, an oestrous cycle-regulated expression of TIMP-1 mRNA, one of the specific inhibitors of MMPs, was observed. The highest expression was detected during ovulation. By reverse zymography techniques, two major bands specific for the inhibition of MMP-2 were observed at $21 \mathrm{kDa}$ and $22 \mathrm{kDa}$. The $21 \mathrm{kDa}$ band showed an oestrous cycle-dependent regulation, with the highest expression after ovulation similar to the mRNA expression of TIMP-1. Satoh et al. (1994) described a $31 \mathrm{kDa}$ protein that was synthesized in bovine oviductal epithelial cell culture and identified as TIMP-1 by $\mathrm{NH}_{2}$-terminal amino acid sequence and western blotting. Buhi et al. (1997) detected a $29 \mathrm{kDa}$ protein as TIMP-1 in pig oviducts, with highest mRNA expression and protein secretion around the time of ovulation. Two TIMP-1 forms of 21 and $29 \mathrm{kDa}$ were detected in bovine retinal interphotoreceptor matrix (Jones et al., 1994). However, in the present study, TIMP-1 was not detected as a high molecular mass form of 29 or $31 \mathrm{kDa}$. These molecular mass differences may be the result of the various degrees of glycosylation of the $21 \mathrm{kDa}$ backbone protein of TIMP-1 (Woessner, 1991), indicating that the $21 \mathrm{kDa}$ protein may be TIMP-1.

TIMP-1 has also been identified as a factor stimulating embryo development in vitro (Satoh et al., 1994). Another property of TIMP-1 is that it acts as a growth-promoting factor on a variety of cell types in vitro (Hayakawa et al., 1992). Taken together, these findings indicate that TIMP-1 may act as an embryotrophic factor during the early development of bovine embryos in the oviduct. Highest MMP-2 and TIMP-1 contents around the time of ovulation in oviductal flushings indicate a well-regulated balance between the protease (MMP-2) and its specific inhibitor (TIMP-1).

The two other proteins with inhibitory activity on gelatinases found in oviductal flushings had molecular masses of approximately 22 and $24 \mathrm{kDa}$, similar to those of TIMP-2 and TIMP-3 (Pavloff et al., 1992), respectively, although confirmation of their identities is necessary. TIMP-2 shows no cell growth-promoting activity (Hayakawa et al., 1992), but inhibits MMP-2 preferentially (Goldberg et al., 1989; Howard et al., 1991) and may play a role in inhibiting MMP-2 in the oviduct. The results of the present study support the concept that components of extracellular matrix, such as UPA, PAI-1, TIMPs, MMP-1 and MMP-2, are produced and secreted by bovine oviductal cells. We propose that the function of these factors is to protect the gametes and the early embryo from proteolytic degradation, to release heparin-binding growth factors from the epithelium surface and to stimulate embryo development. Components of the extracellular matrix components may play an important role in preparing the oviductal environment in vivo for gametes, fertilization and early embryo development.

This research was supported by the DFG (Ei296/4-3) and by USDA (no 96-35203-3428). The authors would like to thank A. Zuber and S. Rode for their technical assistance.

\section{References}

Bieser B, Stojkovic M, Wolf E, Meyer H and Einspanier R (1998) Growth factors and components of extracellular proteolysis are differentially expressed during in vitro maturation of bovine cumulus-oocyte complexes Biology of Reproduction 59 801-806

Blasi F, Vassalli J-D and Danø K (1987) Urokinase-type plasminogen activator: proenzyme, receptor, and inhibitors Journal of Cell Biology 104 801-804

Buhi WC, Alvarez IM, Pickard AR, McIntush EW, Kouba AJ, Ashworth CJ and Smith MF (1997) Expression of tissue inhibitor of metalloproteinase1 protein and messenger ribonucleic acid by the oviduct of cyclic, earlypregnant, and ovariectomized steroid-treated gilts Biology of Reproduction 57 7-15

Chomczynski P and Sacchi N (1987) Single-step method of RNA isolation by acid guanidinium thiocyanate-phenol-chloroform extraction Analytical Biochemistry 162 156-159

Danø K, Andreasen PA, Grondahl-Hansen J, Kristensen P, Nielsen LS and Skriver L (1985) Plasminogen activators, tissue degradation, and cancer Advances in Cancer Research 44 139-266

Einspanier R, Gabler C and Lauer B (1996) Expression of urokinaseplasminogen activator (UPA) is correlated with soluble heparinanalogues and basic fibroblast growth factor (bFGF) in bovine oviducts during oestrous cycle Journal of Reproduction and Fertility Abstract Series 1712 (Abstract 26)

Einspanier R, Müller K, Bieser B, Kosmann M and Schams D (1999) Differential expression of vascular endothelial growth factor (VEGF) in bovine ovarian follicles and first effects of VEGF applied during in vitro maturation of oocytes Journal of Reproduction and Fertility Supplement 237 (Abstract)

Ferrara N and Davis-Smyth T (1997) The biology of vascular endothelial growth factor Endocrine Reviews 18 4-25 
Gabler C, Lauer B, Einspanier A, Schams D and Einspanier R (1997) Detection of mRNA and immunoreactive proteins for acidic and basic fibroblast growth factor and expression of the fibroblast growth factor receptors in the bovine oviduct Journal of Reproduction and Fertility 109 213-221

Gabler C, Plath-Gabler A, Einspanier A and Einspanier R (1998) Insulin-like and fibroblast growth factors and their receptors are differentially expressed in the oviduct of the common Marmoset monkey (Callithrix jacchus) during the ovulatory cycle Biology of Reproduction $\mathbf{5 8}$ 1451-1457

Gabler C, Einspanier A, Schams D and Einspanier R (1999) Expression of vascular endothelial growth factor (VEGF) and its corresponding receptors (flt-1 and flk-1) in the bovine oviduct Molecular Reproduction and Development 53 376-383

Goldberg GI, Marmer BL, Grant GA, Eisen AZ, Wilhelm S and He CS (1989) Human 72-kilodalton type IV collagenase forms a complex with a tissue inhibitor of metalloproteases designated TIMP-2 Proceedings National Academy of Sciences USA 86 8207-8211

Gomez DE, Alonso DF, Hitoshi Y and Thorgeirsson UP (1997) Tissue inhibitors of metalloproteinases: structure, regulation and biological functions European Journal of Cell Biology 74 111-122

Gospodarowicz D, Neufeld G and Schweigerer L (1987) Fibroblast growth factor: structural and biological properties Journal of Cellular Physiology Supplement 5 15-26

Hayakawa T, Yamashita K, Tanzawa K, Uchijima E and Iwata K (1992) Growth-promoting activity of tissue inhibitor of metalloproteinases(TIMP-1) for a wide range of cells FEBS Letters 298 29-32

Herron GS, Banda MJ, Clark EJ, Gavrilovic J and Werb Z (1986) Secretion of metalloproteinases by stimulated capillary endothelial cells. II. Expression of collagenase and stromelysin activities is regulated by endogenous inhibitors Journal of Biological Chemistry $2612814-2818$

Heussen C and Dowdle EB (1980) Electrophoretic analysis of plasminogen activators in polyacrylamide gels containing sodium dodecyl sulfate and copolymerized substrates Analytical Biochemistry 102 196-202

Houck KA, Leung DW, Rowland AM, Winer J and Ferrara N (1992) Dua regulation of vascular endothelial growth factor bioavailability by genetic and proteolytic mechanism Journal of Biological Chemistry 267 26031-26037

Howard EW, Bullen EC and Banda MJ (1991) Preferential inhibition of 72 and $92-\mathrm{kDa}$ gelatinases by tissue inhibitor of metalloproteinases-2 Journal of Biological Chemistry 266 13070-13075

Ireland JI, Murphee RL and Coulson PB (1980) Accuracy of predicting stages of bovine estrous cycle by gross appearance of the corpus luteum Journal of Dairy Science 63 155-160

Jones BE, Moshyedi P, Gallo S, Tombran-Tink J, Arand G, Reid DA, Thompson EW, Chader GJ and Waldbillig RJ (1994) Characterization and novel activation of $72-\mathrm{kDa}$ metalloproteinase in retinal interphotoreceptor matrix and Y-79 cell culture medium Experimental Eye Research 59 257-269

Karlan BY, Clark AS and Littlefield BA (1987) A highly sensitive chromogenic microtiter plate assay for plasminogen activators which quantitatively discriminates between the urokinase and tissue-type activators Biochemical and Biophysical Research Communications 142 147-154

Kouba AJ, Alvarez IM and Buhi WC (2000a) Identification and localization of plasminogen activator inhibitor-1 within the porcine oviduct Biology of Reproduction 62 501-510

Kouba AJ, Burkhardt BR, Alvarez IM, Goodenow MM and Buhi WC (2000b) Oviductal plasminogen activator inhibitor-1 (PAI-1): mRNA protein, and hormonal regulation during the estrous cycle and early pregnancy in the pig Molecular Reproduction and Development $\mathbf{5 6}$ 378-386

Krätzschmar J, Haendler B, Kojima S, Rifkin DB and Schleunig WD (1993 Bovine urokinase-type plasminogen activator and its receptor: cloning and induction by retinoic acid Gene 125 177-183

Larson RC, Ignotz GG and Currie WB (1992) Transforming growth factor $\beta$ and basic fibroblast growth factor synergistically promote early bovine embryo development during the fourth cell cycle Molecular Reproduction and Development 33 432-435
Leese HJ (1988) The formation and function of oviduct fluid Journal of Reproduction and Fertility 82 843-856

Mayer M (1990) Biochemical and biological aspects of the plasminogen activation system Clinical Biochemistry 23 197-211

Mazzieri R, Masiero L, Zanetta L, Monea S, Onisto M, Garbisa S and Mignatti P (1997) Control of type IV collagenase activity by components of the urokinase-plasmin system: a regulatory mechanism with cellbound reactants EMBO Journal 16 2319-2332

Montesano R, Vassalli JD, Baird A, Guillemin R and Orci L (1986) Basic fibroblast growth factor induces angiogenesis in vitro. Proceedings National Academy of Sciences USA 83 7297-7301

Moscatelli D (1986) Urokinase-type and tissue-type plasminogen activators have different distributions in cultured bovine capillary endothelial cells Journal of Cellular Biochemistry 30 19-29

Oliver GW, Leferson JD, Stetler-Stevenson WG and Kleiner DE (1997) Quantitative reverse zymography: analysis of picogram amounts of metalloproteinase inhibitors using gelatinase $A$ and $B$ reverse zymograms Analytical Biochemistry 244 161-166

Pavloff N, Staskus PW, Kishnani NS and Hawkes SP (1992) A new inhibitor of metalloproteinases from chicken: ChIMP-3. A third member of the TIMP family Journal of Biological Chemistry 267 17321-17326

Pepper MS, Ferrara N, Orci L and Montesano R (1991) Vascula endothelial growth factor (VEGF) induces plasminogen activators and plasminogen activator inhibitor-1 in microvascular endothelial cells Biochemical and Biophysical Research Communications 181 902-906

Plath A, Peters F and Einspanier R (1996) Detection and quantitation of specific mRNAs by ribonuclease protection assay using denaturing horizontal polyacrylamide gel electrophoresis: a radioactive and nonradioactive approach Electrophoresis 17 471-472

Saksela O and Rifkin DB (1988) Cell-associated plasminogen activation: regulation and physiological functions Annual Review of Cell Biology 4 93-126

Saksela O and Rifkin DB (1990) Release of basic fibroblast growth factorheparan sulfate complexes from endothelial cells by plasminogen activator-mediated proteolytic activity Journal of Cell Biology $\mathbf{1 1 0}$ $767-775$

Salamonsen LA (1999) Role of proteases in implantation Reviews of Reproduction 4 11-22

Satoh T, Kobayashi K, Yamashita S, Kikuchi M, Sendai Y and Hoshi H (1994) Tissue inhibitor of metalloproteinases (TIMP-1) produced by granulosa and oviduct cells enhances in vitro development of bovine embryos Biology of Reproduction 50 835-844

Schmidt A, Einspanier R, Amselgruber W, Sinowatz F and Schams D (1994) Expression of insulin-like growth factor 1 (IGF-1) in the bovine oviduct during the oestrous cycle Experimental and Clinical Endocrinology 102 364-369

Tiemann U, Neels P, Kuchenmeister U, Walzel H and Spitschak M (1996) Effect of ATP and platelet-activating factor on intracellular calcium concentrations of cultured oviductal cells from cows Journal of Reproduction and Fertility 108 1-9

Viuff D, Hyttel P, Greve T, Eriksen T and Alexandersen S (1995) Transcription and localization of growth factor mRNA in the bovine oviduct Molecular Reproduction and Development 42 28-34

Watson AJ, Hogan A, Hahnel A, Wiemer KE and Schultz GA (1992) Expression of growth factor ligand and receptor genes in the preimplantation bovine embryo Molecular Reproduction and Development 31 87-95

Winger QA, de los Rios P, Han VKM, Armstrong DT, Hill DJ and Watson AJ (1997) Bovine oviductal and embryonic insulin-like growth factor binding proteins: possible regulators of "embryothropic" insulin-like growth factor circuits Biology of Reproduction 56 1415-1423

Woessner JF, Jr (1991) Matrix metalloproteinases and their inhibitors in connective tissue remodeling FASEB Journal 5 2145-2154

Received 16 November 2000

First decision 22 January 2001.

Accepted 19 March 2001. 